\section{Social and biological determinants of iron deficiency anemia}

\author{
Determinação social e biológica \\ da anemia ferropriva
}

\author{
1 Universidade Federal de \\ Viçosa, Viçosa, Brasil. \\ Correspondence \\ R. M. M. Cotta \\ Universidade Federal de \\ Viçosa. \\ Av. Peter Henry Rolfs $s / n$ \\ Campus Universitário, Viçosa, \\ MG 36570-000, Brasil. \\ rmmitre@ufv.br
}

\section{Abstract}

This cross-sectional study aimed to identify the social and biological determinants of anemia in children enrolled in the Brazilian Income Transfer Program (PBF). The study evaluated 446 children (69.1\% of the total enrolled) ranging from 6 to 84 months of age, of whom 262 were receiving the income transfer (60.2\% of the beneficiaries) and 184 were not (87.6\% of the non-beneficiaries). Testing for anemia was performed with the Hemocue portable hemoglobinometer, and the cutoff points were set at 11.0 and $11.5 \mathrm{~g} / \mathrm{dL}$, according to age bracket. The data were analyzed using Poisson hierarchical regression with robust variance for multivariate analysis. There was no difference in the anemia prevalence rates between the beneficiary and non-beneficiary groups. Risk factors for anemia were low paternal schooling, cesarean birth, consumption of untreated water, stunting, and age less than 24 months. Prevalence of anemia in the group of non-beneficiary children under two years of age was significantly higher than in the beneficiary group in the same age bracket, suggesting the importance of the PBF income transfer for preventing anemia in children.

Anemia; Government Programs; Risk Factors; Income
Rosângela Minardi Mitre Cotta 1 Fabiana de Cássia Carvalho Oliveira 1 Kelly Alves Magalhães 1 Andréia Queiroz Ribeiro 1 Luciana Ferreira da Rocha Sant'Ana 1 Silvia Eloiza Priore 1 Sylvia do Carmo Castro Franceschini 1

\section{Introduction}

Social determinants of health are defined as the social conditions in which people live and work that influence the occurrence of health problems and their risk factors in the population, such as type of housing, income, lifestyle, the economic policy of the country in which they live, and others. Thus, health promotion requires intense action in the broad social determinants of health, ranging from interlocution between society's socioeconomic, cultural, and environmental policies to the creation of educational programs to change personal habits 1,2. Meanwhile, in the context of social determination of diseases, iron deficiency anemia stands out as the principal nutritional deficiency affecting children worldwide, besides the close relationship between this disease and unfavorable social and environmental conditions 3 .

The World Health Organization (WHO) estimates that, worldwide, approximately $47 \%$ of children under five years of age are anemic, while in Brazil the figure reaches 55\% 4,5. Although this nutritional deficiency can affect all socioeconomic strata, anemia is more prevalent among the underprivileged classes 6 , which emphasizes the importance of social determinants of health in the development of this deficiency. Given the high prevalence and the vulnerable conditions of children belonging to these socioeconomic 
classes, anemia can be considered a serious public health problem in Brazil.

The determinants of anemia in children appear to vary according to age bracket. In infants, the principal factors related to this deficiency are low intake of bioavailable iron, rapid growth (characteristic of this age), and early weaning 7 . In children over two years of age, family income appears to be the factor with the greatest influence on hemoglobin levels, since in this age bracket the child's diet is similar to that of the family, and income prevails in acquiring foods containing iron 8. Qualitative and quantitative iron deficiency in the diet, combined with unfavorable environmental conditions, favor the broad dissemination of iron deficiency in Brazil, especially among poor families.

In order to combat these and other health inequalities, continuous planning and the implementation of inter-sectorial government actions are needed. Thus the important role in Brazil of direct income transfer programs, including the Brazilian Income Transfer Program (PBF), which have been proposed to use income increments in order to improve the population's nutritional and health conditions.

The PBF is part of a network of social protection and anti-poverty policies targeting poor families which are generally subject to multiple vulnerabilities 9 . Aimed at fighting poverty and hunger, the program promotes food and nutritional security and encourages the sustained emancipation of beneficiary families by granting a monetary stipend, the family's compliance in the areas of education and health, and the supply of complementary actions and programs for employment and income generation 10 .

Given the social vulnerability of families dependent on direct income transfer programs, and given the importance of iron deficiency anemia as a public health problem in Brazil, this study aimed to verify the prevalence of anemia and associated factors in children from families enrolled in the PBF, residing in the Zona da Mata in Minas Gerais State.

\section{Study subjects and methods}

\section{Characterization of the study population and location}

This was a cross-sectional study in the municipality (county) of Paula Cândido, located in the Zona da Mata in Minas Gerais State, from September to November 2007. According to the most recent National Census at the time of the study (2000), the municipality had a population of $9,109,57 \%$ of whom living in the countryside. Approximately $30 \%$ of the population had no nominal income, and $8 \%$ had less than one year of schooling. The Gini index was 0.42 and the poverty rate was $32.94 \%$ (Instituto Brasileiro de Geografia e Estatística. Population Data. http:// www.ibge.gov.br/cidadesat/default.php, accessed on 08/Mar/2007; United Nations Development Program. Human Development Atlas. http://www.pnud.org.br/atlas, accessed on 20/ Jun/2007).

\section{Sampling}

The inclusion criterion for the current study was that the child must belong to a family enrolled in the PBF with a monthly per capita income less than $\mathrm{R} \$ 120.00$ (the threshold value required by the PBF). The enrolled families that were already receiving the income transfer were defined as "beneficiaries", and those that were enrolled but were not receiving the transfer were defined as "non-beneficiaries". The inclusion of both groups of families in the study aimed to compare the children's nutritional status according to whether they were receiving the financial stipend.

The records were provided by the City Department of Social Assistance (Secretaria Municipal de Assistência Social), and at the time of the study there were 875 families enrolled in the PBF. These families had 645 children from 6 to 84 months of age, of which 435 were beneficiaries and 210 non-beneficiaries. The age bracket was chosen because it corresponded to the age in which children were under nutritional followup as a condition for the PBF, and it was thus the program's priority.

To cover the widest possible number of children, the study chose to evaluate the non-beneficiary group (210) and the same number of children from the beneficiary group, with the latter chosen by simple random selection. There were losses in the non-beneficiary group due to nonattendance in the nutritional evaluation and child's refusal to submit to the hemoglobin test, thus resulting in 184 children $(87.6 \%$ of all nonbeneficiaries enrolled in the PBF). In the beneficiary group, since some mothers took the target child's siblings along to be included in the study, there was a slight increase in the sample, finally totaling 262 children $(60.2 \%$ of all the enrolled beneficiary children).

In short, the study evaluated 446 children enrolled in the PBF $(69.1 \%$ of all the enrolled children), ranging from 6 to 84 months of age and belonging to two distinct groups: beneficiaries (BF group) and non-beneficiaries (NBF group) enrolled in the program. 


\section{Data collection}

The equipment used to measure hemoglobin levels was the Hemocue portable hemoglobinometer (HemoCue Inc., Laguna Hills, USA), and the cutoff points for anemia were those recommended by the WHO: $11.0 \mathrm{~g} / \mathrm{dL}$ for children 6-59 months of age and $11.5 \mathrm{~g} / \mathrm{dL}$ for children $60-84$ months of age. The follow cutoff points were used to classify the degree of anemia: less than $7.0 \mathrm{~g} / \mathrm{dL}$ for severe anemia; $7.0 \mathrm{~g} / \mathrm{dL}-9 / 9 \mathrm{~g} / \mathrm{dL}$ for moderate anemia; and $10.0 \mathrm{~g} / \mathrm{dL}-10.9 \mathrm{~g} / \mathrm{dL}$ for mild anemia in children 6-59 months of age and $10.0 \mathrm{~g} / \mathrm{dL}$ $11.4 \mathrm{~g} / \mathrm{dL}$ for children $60-84$ months of age 11.

Stature/length was measured using the techniques recommended by Jelliffe 12 . Classification of stunting used the cutoff of $-2.00 \mathrm{z}$-scores for the height/age index, according to the WHO international reference for 200613 .

Parents or guardians were interviewed with semi-structured questionnaires containing questions on eating, health, and socioeconomic patterns for the children and their families. The questionnaire was prepared by the research team in charge of the project, based on previous studies 14,15.

The social and sanitary variables were: number of persons in the household, family and per capita income, parents' schooling, type of water supply and treatment, sewage connection, and garbage collection. The maternal and child health variables were: history of abortions, smoking, and alcohol consumption, history of chronic diseases in the family, type of delivery, prematurity, birth weight and length, prenatal care, breastfeeding, vaccination schedule, consumption of cow's milk, presence of physical, mental, or chronic non-communicable diseases, history of disease, hospitalization, anemia, and intestinal parasite infections, previous or current use of medication for anemia, eating habits, and lifestyle.

Data on birth weight and length were obtained from the child's health card. Current stature and hemoglobin level were measured by the researchers, who were trained nutritionists. The other variables were reported by the child's mother or guardian.

\section{Statistical analysis}

Initially, the Kolmogorov-Smirnov test was applied to verify distribution of the variables. In the bivariate analysis, Pearson's chi-square (Pearson's $\chi^{2}$ ) was used to verify the association between categorical variables, and Student's t-test or Mann-Whitney test was used to analyze discrete variables, according to the variable's dis- tribution. For all the tests, the significance level for rejection of the null hypothesis was set at less than $5 \%$. According to the results of the bivariate analysis, the variables selected for the multivariate modeling were those associated with the dependent variable with $\mathrm{p}<0.25$. The associations were tested between anemia and all the previously mentioned variables.

In the multivariate analysis, determination of the factors independently associated with the outcome (anemia) used Poisson hierarchical regression with robust variance, with estimation of prevalence ratios (PR). Poisson regression analysis was chosen because PR is the recommended measure of association for cross-sectional studies with binary outcomes 16 .

The model adopted for hierarchization was that proposed by Victora et al. 17, in which the variables are organized in three blocks, based on the logical and theoretical relations between the determinant factors. This model was adapted for anemia, as in the studies by Silva et al. 18 and Bueno et al. 19. The first (more distal) block deals with structural processes in society; the second block (intermediate) relates to processes in the child's immediate surroundings; and the third (more proximal) block includes the child's individual processes. Thus, the more distal variables served as adjustment factors for the hierarchically lower blocks, and were maintained in the other models, even when they lost statistical significance.

Figure 1 provides a schematic of the hierarchical model used in this study for the determination of anemia.

Seeking to identify the different factors involved in the determination of anemia according to the child's age, two models were constructed, based on the same methodology described above, for children 24 months or younger and over 24 months of age.

Among children two years or younger, the variables that proved to be possible confounding factors $(p<0.25)$ and which thus underwent multivariate analysis were as follows: in the first block, paternal schooling; in the second, place of residence, number of persons in the household, running water, and consumption of untreated water; and in the third, more proximal block, exclusive breastfeeding for less than three months (median), drinking milk at meals, nonconsumption of natural fruit juice during or right after meals, incomplete vaccination, chronic illness, and stunting.

Among children over two years of age, the factors comprising the distal block were per capita income and paternal schooling. The intermediate block included such variables as type 
of delivery, number of persons in the household, number of siblings, consumption of untreated water, and teenage motherhood. The more proximal block, referring to the child's individual characteristics, included history of anemia, intestinal parasites, and stunting.

In the interpretation of the findings from the regression, $\mathrm{p}<0.05$ was defined as indicative of a significant and independent association between a given variable and presence of anemia, after adjusting for possible confounding factors from the same block and the hierarchically higher blocks. Prevalence ratio was chosen as the measure of association.

The software packages used for constructing the databank and performing the statistical analyses were Epi Info, version 6.04 (Centers for Disease Control and Prevention, Atlanta, USA) and Stata, version 7.0 (Stata Corp., College Station, USA).

\section{Ethical issues}

The project received prior approval by the Ethics Research Committee in Human Beings at the Viçosa Federal University (Universidade Federal de Viçosa), case no. 095/2007, in compliance with Ruling $n^{\circ}$. 196/1996 of the Brazilian National Health Council (Conselho Nacional de Saúde). All the children examined received authorization to participate from parents or guardians, who signed a free and informed consent form.

Figure 1

Hierarchical model for the determination of iron deficiency anemia.

Distal block - Structural processes in society

- Paternal schooling
- Per capita income

Intermediate block - Processes in the child's immediate environment

- Number of persons in household

- Untreated drinking water

- Type of delivery

- Number of siblings

Proximal block - Child's individual processes

- Chronic illness

Stunting (height/age $<-2.00$ z-scores)

- Age $<24$ months (age bracket at greatest risk of anemia according to the literature)

Age $<24$ month
Milk at meals

- History of anemia

- History of intestinal parasites

- History of medication for anemia 


\section{Results}

Of the 446 children that were examined, $51.8 \%$ were boys, median age was 47 months (range 6-84 months), and $21.3 \%$ were under two years of age.

\section{Socioeconomic characteristics}

The majority of the fathers (65.6\%) and mothers $(54.8 \%)$ had four years of schooling or less. Table 1 shows socioeconomic characteristics of the groups, according to income transfer status. The beneficiary families had a lower mean family and per capita income, fewer persons in the household, and lower maternal and paternal schooling as compared to non-beneficiaries. However, when the income transfer was included in the total income, the beneficiary families received a statistically higher total family income and similar per capita income compared to nonbeneficiaries.

As for basic sanitation, non-beneficiary families showed a higher rate of garbage collection (55.5\% vs. $46.2 \%)$, running water supply (53.3\% vs. $43.9 \%$ ), public sewage connection $(69 \%$ vs. $67.4 \%)$, and water treatment by filtration $(77.4 \%$ vs. $76.2 \%)$, but these differences were not significant ( $\mathrm{p}>0.05)$.

\section{Iron deficiency anemia}

Among the 446 children, 443 were tested for anemia. Mean hemoglobin was $11.87 \pm 1.20 \mathrm{~g} / \mathrm{dL}$, and anemia prevalence was $22.6 \%$, of which $69 \%$ mild, $30 \%$ moderate, and $1 \%$ severe. There was no significant association between presence of anemia and gender, either for the entire group or among beneficiaries and non-beneficiaries.

Anemia prevalence was $22 \%$ in the group receiving the PBF income transfer and $23.4 \%$ in the group without the transfer, with no statistically significant difference between the groups. When comparing mean hemoglobin levels, there was also no significant difference between the groups $(11.94 \pm 1.25 \mathrm{~g} / \mathrm{dL}$ in the BF group and $11.79 \pm$ $1.13 \mathrm{~g} / \mathrm{dL}$ in NBF).

Evaluating anemia according to age bracket and the income transfer, there was no statistical difference between the BF and NBF groups in any of the age brackets, as shown in Figure 2.

\section{Social and biological determinants of anemia}

Table 2 shows the determinants of anemia that remained significant in the final multivariate analysis in this sample of children.

In the more distal block, only paternal schooling was independently associated with anemia, that is, anemia prevalence among children whose fathers had less schooling was 1.6 times higher than the prevalence in children whose fathers had more schooling.

In the second block, referring to maternal and environmental characteristics, the variables type of delivery and consumption of untreated water remained significant in the final model. In this study, the cesarean rate was $32 \%$, with no statistically significant difference between the BF and NBF groups. In relation to drinking water, $14.9 \%$ of the children's parents reported consuming untreated water. Consumption of untreated water

Socioeconomic characteristics of families enrolled in the Brazilian Income Transfer Program, according to income transfer beneficiary versus non-beneficiary status. Paula Cândido, Minas Gerais State, Brazil, 2007.

\begin{tabular}{|c|c|c|c|c|c|}
\hline \multirow[t]{2}{*}{ Characteristics } & \multicolumn{2}{|c|}{ BF Group } & \multicolumn{2}{|c|}{ NBF Group } & \multirow[t]{2}{*}{ p-value } \\
\hline & $X \pm S D$ & Median & $X \pm S D$ & Median & \\
\hline Family income, excluding the transfer (in Reais) & $335.10 \pm 139.40$ & 380.00 & $391.40 \pm 245.00$ & 380.00 & $0.01 *$ \\
\hline Family income, including the transfer (in Reais) & $413.96 \pm 136.66$ & 416.00 & $391.40 \pm 245.00$ & 380.00 & $<0.001$ * \\
\hline Per capita income, excluding the transfer (in Reais) & $69.60 \pm 31.31$ & 63.30 & $94.70 \pm 72.00$ & 85.70 & $<0.001$ * \\
\hline Per capita income, including the transfer (in Reais) & $85.38 \pm 30.14$ & 82.40 & $94.70 \pm 72.00$ & 85.70 & $0.94 *$ \\
\hline Number of members living in household & $5.0 \pm 1.5$ & 5 & $4.6 \pm 2.0$ & 4 & $<0.001 *$ \\
\hline Paternal schooling (years) & $4.4 \pm 2.4$ & 4 & $5.2 \pm 2.7$ & 4 & $0.002 * \star$ \\
\hline Maternal schooling (years) & $4.9 \pm 2.4$ & 4 & $5.7 \pm 2.7$ & 5 & 0.005 * \\
\hline
\end{tabular}

BF: beneficiaries; NBF: non-beneficiaries; $\mathrm{X} \pm \mathrm{SD}=$ mean \pm standard deviation.

* Mann-Whitney;

** Student's t test. 
Figure 2

Anemia prevalence in beneficiary and non-beneficiary groups, according to age. Paula Cândido, Minas Gerais State, Brazil, 2007.

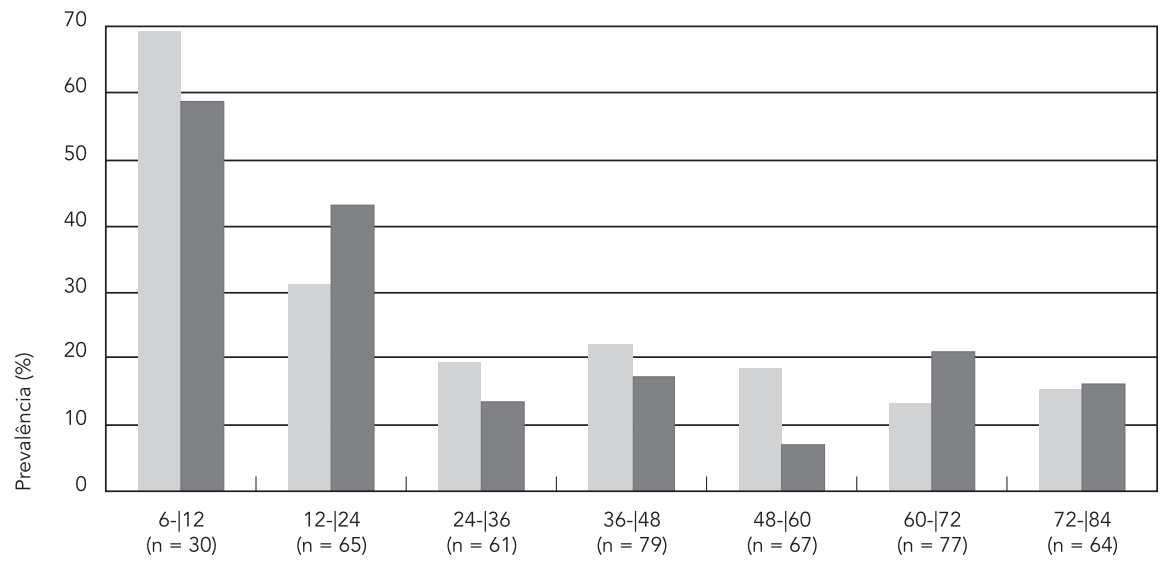

Beneficiary

Non-beneficiary

$p>0.05$ for $\chi^{2}$ test between beneficiary and non-beneficiary groups, $n=443$

Table 2

Results of Poisson regression analysis with robust variance in children 6-84 months of age enrolled in the Brazilian Income Transfer Program. Paula Cândido, Minas Gerais State, Brazil, 2007.

\begin{tabular}{|c|c|c|c|c|}
\hline \multirow[t]{2}{*}{ Variables } & \multicolumn{2}{|c|}{ Crude } & \multicolumn{2}{|c|}{ Adjusted } \\
\hline & PR & $95 \% \mathrm{Cl}$ & PR & $95 \% \mathrm{Cl}$ \\
\hline \multicolumn{5}{|l|}{ Block 1} \\
\hline \multicolumn{5}{|l|}{ Paternal schooling (years) } \\
\hline$>4$ & 1.00 & & & \\
\hline$\leq 4$ & 1.62 & $1.01-2.60$ & & \\
\hline \multicolumn{5}{|l|}{ Block 2 * } \\
\hline \multicolumn{5}{|l|}{ Type of delivery } \\
\hline Vaginal & 1.00 & & 1.00 & \\
\hline Cesarean & 1.46 & $1.02-2.08$ & 1.61 & $1.09-2.38$ \\
\hline \multicolumn{5}{|l|}{ Drinking water } \\
\hline Boiled, filtered, or chlorinated & 1.00 & & 1.00 & \\
\hline Untreated & 1.61 & $1.08-2.39$ & 1.68 & $1.08-2.61$ \\
\hline \multicolumn{5}{|l|}{ Block 3 ** } \\
\hline \multicolumn{5}{|l|}{ Stunting } \\
\hline No & 1.00 & & 1.00 & \\
\hline Yes & 2.22 & $1.43-3.45$ & 2.01 & $1.18-3.42$ \\
\hline \multicolumn{5}{|l|}{ Child's age (months) } \\
\hline$>24$ & 1.00 & & 1.00 & \\
\hline$\leq 24$ & 2.76 & $1.99-3.82$ & 2.82 & $1.94-4.10$ \\
\hline
\end{tabular}

95\% $\mathrm{Cl}$ : 95\% confidence interval; PR: prevalence ratio.

* Adjusted for the variable paternal schooling and the variable from the same block;

** Adjusted for the variables paternal schooling, type of delivery, and untreated drinking water, and for the variable from the same block. 
was 1.68 times higher in children with anemia as compared to those without anemia.

Among children who had done stool tests (68.9\%), 31.8\% tested positive for some type of intestinal parasite. Considering only children less than 24 months of age, only $35.5 \%$ had been tested for parasites, and $26.7 \%$ of these tested positive.

In the third block (proximal), age two years or less and stunting (height-for-age deficit) were independently associated with anemia. As for PR estimates, anemia prevalence in children with stunting ( $P R=2.01)$ was double that of children with normal stature. Among children less than two years of age, anemia prevalence was nearly triple $(\mathrm{PR}=2.82)$ that of children more than two years of age. Importantly, stunting was present in $6.3 \%$ of the children.

Furthermore, age less than or equal to 24 months was associated with anemia in the BF and NBF groups, but with different magnitudes.
In the NBF group, anemia prevalence in children 24 months or younger was 3.37 that of older children, while in the BF group it was 2.12 times higher (BF: PR = 2.12; 95\%CI: 1.33-3.38; NBF: PR = 3.37; 95\%CI: 2.04-5.54).

The analysis of factors independently associated with anemia according to age bracket (Table 3) showed that in children two years or younger the variables comprising the final model were drinking untreated water and not consuming natural fruit juice during or right after meals. Among children over two years old, the risk factors for anemia were cesarean birth, history of anemia, and stunting.

\section{Discussion}

Generally speaking, the population enrolled in the PBF in the municipality (both beneficiaries and non-beneficiaries) lived in situations of

Table 3

Results of the Poisson regression analysis with robust variance in children 6-84 months of age enrolled in the Brazilian Income Transfer Program, according to age bracket. Paula Cândido, Minas Gerais State, Brazil, 2007.

\begin{tabular}{|c|c|c|c|c|}
\hline \multirow[t]{2}{*}{ Variables } & \multicolumn{2}{|c|}{ Crude } & \multicolumn{2}{|c|}{ Adjusted } \\
\hline & PR & $95 \% \mathrm{Cl}$ & PR & $95 \% \mathrm{Cl}$ \\
\hline \multicolumn{5}{|l|}{ Under 24 months of age } \\
\hline \multicolumn{5}{|l|}{ Block 2} \\
\hline \multicolumn{5}{|l|}{ Drinking water } \\
\hline Boiled, filtered, or chlorinated & 1.00 & & & \\
\hline Untreated & 1.75 & $1.14-2.68$ & & \\
\hline \multicolumn{5}{|l|}{ Block 3 * } \\
\hline \multicolumn{5}{|l|}{ Natural fruit juice at meals } \\
\hline Yes & 1.00 & & 1.00 & \\
\hline No & 1.78 & $1.12-2.83$ & 1.76 & $1.15-2.71$ \\
\hline \multicolumn{5}{|l|}{ Over 24 months of age } \\
\hline \multicolumn{5}{|l|}{ Block 2} \\
\hline \multicolumn{5}{|l|}{ Type of delivery } \\
\hline Vaginal & 1.00 & & & \\
\hline Cesarean & 1.71 & $1.05-2.78$ & & \\
\hline \multicolumn{5}{|l|}{ Block $3 * \star$} \\
\hline \multicolumn{5}{|l|}{ History of anemia } \\
\hline No & 1.00 & & 1.00 & \\
\hline Yes & 2.29 & $1.22-4.30$ & 2.70 & $1.21-6.01$ \\
\hline \multicolumn{5}{|l|}{ Stunting } \\
\hline No & 1.00 & & 1.00 & \\
\hline Yes & 2.66 & $1.46-4.83$ & 2.42 & $1.15-5.07$ \\
\hline
\end{tabular}

95\% Cl: 95\% confidence interval; PR: prevalence ratio.

* Adjusted for the variable untreated drinking water;

** Adjusted for type of delivery. 
social vulnerability, because in addition to low income, they displayed low schooling and inadequate basic sanitation. However, those that were not only enrolled but were already receiving the income transfer (and who had shown significantly worse socioeconomic conditions prior to the transfer) now had equivalent per capita income to that of the NBF group. Thus, we can assume that the PBF is contributing significantly to the beneficiary families' escape from poverty.

One possible hypothesis is that the financial increment that produced statistical equality between the groups in terms of per capita income may also have provided the same equality observed in hemoglobin levels, if the income transfer was indeed used to purchase foods with high nutritional value and in sufficient amounts. It was beyond the scope of the current article to verify how the income transfer was spent, but studies evaluating the PBF 9,15,20 have shown that families used the transfer to purchase food. However, in order to confirm whether the income transfer actually improves hemoglobin levels, a longitudinal study would be necessary, evaluating the groups before and after receiving the stipend.

Anemia prevalence among the total sample of children was high, but lower than in other Brazilian studies. According to one study, in the city of São Paulo anemia prevalence was $68.7 \%$ of children under 75 months of age attending public daycare centers 19. In Pontal, São Paulo State, prevalence of iron deficiency anemia was $51.3 \%$ in children under 72 months ${ }^{21}$. A study in Pelotas, Rio Grande do Sul State, showed 30.2\% of children under 6 years of age with anemia 22 . In Pernambuco State, anemia prevalence in children 6-59 months of age was $40.9 \% 23$. In the Western Brazilian Amazon, in the municipalities (counties) of Acrelândia and Assis Brasil, $30.6 \%$ of children in this same age bracket were anemic 24 .

The current study showed that age less than two years was an important determinant of anemia, thus corroborating other studies 23,25 . In the first two years of life, children experience intense growth and development, generating a high demand for iron, besides making them more susceptible to infections. This increased demand for iron is not always met by their diet, especially in underprivileged social classes. In addition, during the period in which complementary feeding is introduced, the diet offered to infants is predominantly milk-based and monotonous, without important sources of iron or vitamin C, thereby exacerbating the risk of anemia. As children grow older, their diet becomes more varied and increases in quantity, and can thus meet the demand for iron 26. More attention should be fo- cused on children in the second six months of life, in whom (according to the current study) anemia prevalence reached nearly $70 \%$ in families receiving the PBF income transfer and 59\% among non-beneficiaries.

The impact of social determinants on iron deficiency anemia has been widely studied, and the factors with the greatest influence on the development of this deficiency are family and per capita income, maternal schooling, place of residence, and household crowding 27,28,29. In the current study, paternal schooling was independently associated with anemia, corroborating previous studies 14,30 . The role of paternal schooling is directly connected to income, while maternal schooling is connected to childcare, especially in a population where the majority of mothers are housewives. Higher levels of schooling in parents can provide better work opportunities and consequently better income, thus expanding access to diet with better quality and greater variety, in addition to improving the environment in which the child lives.

Anemia was more prevalent in children that consumed untreated water, for the whole sample as well as for those under 24 months of age. This habit can lead to the development of intestinal parasites and diarrhea, which have been identified as risk factors for anemia $31,32,33$. In children in Tanzania, intestinal parasite infections were an important predictive variable for anemia, accounting for $6 \%$ of this deficiency ${ }^{31}$. In Brazil, in a study in Aracajú, Sergipe State, the authors observed an association between intestinal parasites and poor sanitation, but not between intestinal parasites and anemia 32 . Thus, this association remains controversial and merits further clarification.

The current study detected an increased risk of anemia in children of cesarean births, which may be due to the fact that this form of delivery leads to intense bleeding, nearly double that of vaginal delivery 34 , and thus the iron supply to the neonate through the umbilical cord may be reduced.

In addition to type of delivery, history of anemia was independently associated with current anemia among children over two years of age. The observation of this association only in this age group may be partially explained by the fact that $71 \%$ of the children less two years of age had never done routine blood chemistry tests. This result may be directly linked to low adherence to iron supplementation, due mainly to the occurrence of adverse reactions like nausea, vomiting, colic, and diarrhea.

Among the proximal determinants, anemia prevalence in children with stunting was signifi- 
cantly higher than in those with normal stature. The relationship between anemia and nutritional status is still controversial, but among studies that have found such an association, it occurs more frequently with stunting $14,30,35$. The current study's cross-sectional design did not allow establishing this association's temporal relationship. Meanwhile, it is known that once under-nutrition is installed, the individual's food restriction can lead to other types of nutritional deficiencies, including iron deficiency. In addition, protein deprivation means that hemoglobin levels drop by approximately $20 \%$, which appears to be the body's adaptation to the reduction in muscle tissue 36 .

Another hypothesis for this association is that these two nutritional disorders share common determinants, like low parental schooling, precarious basic sanitation, and inadequate diet 35 . However, the Brazilian epidemiological scenario shows opposing trends for the two deficiencies, because while prevalence rates for undernutrition are in full decline, anemia prevalence remains at worrisome levels 26.

An important finding was that among children under two years of age, the prevalence ratio in the NBF group was higher than in the $\mathrm{BF}$ group. This results shows that NBF children under two years of age, even with some more favorable social determinants as compared to the BF group, may be more vulnerable to developing anemia, and one explanation would be that the NBF group is not subject to the conditions set by the PBF, and their health thus receives less care and attention. Therefore, a question that merits further investigation is whether families that receive the $\mathrm{PBF}$ income transfer receive more adequate healthcare (including nutritional follow-up) than non-beneficiaries, because they are subject to the program's conditions.

Children under two years of age that did not consume natural fruit juice during or right after meals showed significantly higher anemia prevalence than in those that drank juice at meals. Vitamin C favors the absorption of non-heme iron, since it reduces the iron ion from its ferric to its ferrous form, which is more soluble, besides preventing the iron ion from binding to other ingredients in the diet that hinder iron absorption 27 . Since these children were from low-income families (which tend to consume less meat and juices/fruits) and belonged to a vulnerable age group, increasing the habit of consuming natural fruit juice during or right after meals would make a major difference in the iron nutritional status of these children.

\section{Final remarks}

It is essential for anemia to be understood as a multi-factorial deficiency that has not only biological factors, but also important social determinants in its causality. The PBF, as a state policy, is part of the more distal social determinants of health. Together with other policies in the socioeconomic sphere, the program impacts the target group's living and work conditions, as well as their access to education and health services. Thus, the program's activities should be increasingly discussed and implemented from an intersectorial and participatory perspective which deals with the complexity of the problems it is intended to confront.

This study showed similar prevalence rates for anemia in the BF and NBF groups. However, among children under two years of age, the non-beneficiary group was more vulnerable to anemia, thus highlighting the need for further investigation of a possible protective effect in the BF group, due to the nutritional follow-up linked to the program's conditions.

Anemia is a public health problem of a multicausal nature, and its determinants interact to different degrees in each individual. This involves greater difficulty in measuring the determinants, one of the main reasons for using models with hierarchical selection to investigate such factors.

The current study allowed identifying subgroups more vulnerable to anemia within a relatively homogeneous population. Thus, among children enrolled in the PBF, the most important risk factors were age under two years, stunting, drinking untreated water, cesarean birth, and parental schooling less than four years. These findings are important for backing the launch and/ or ongoing implementation of social and health policies.

Furthermore, in keeping with the literature, the determinants of anemia are different for children under versus over two years of age. Although income is not a limiting factor in this age, the same cannot be said for the child's environment, including consumption of untreated water. Thus, given the serious consequences of anemia in lowincome children under two years of age, surveillance of iron deficiency anemia should continue to be a priority on the public health agenda for children, with initiatives like the National Iron Supplementation Program targeting the most vulnerable groups.

Interventions in the social determinants of anemia should range from the proximal levels, amenable to individual control, to the more distal ones, which are more related to the country's broader social context. From this perspective, the 
PBF plays an important role due to its potential impact on the living conditions of beneficiary families. However, it should be emphasized that such support measures must be combined with structural actions, for example improvements in sanitation and housing conditions and in the quality of health services and education, which tend to boost the program's effects.

\section{Resumo}

Neste estudo transversal, objetivou-se conhecer a determinação social e biológica da anemia em crianças cadastradas no Programa Bolsa Família (PBF). Foram avaliadas 446 crianças $(69,1 \%$ do total cadastrado) com idade entre 6 e 84 meses, sendo que 262 (60,2\%) recebiam o benefício, e 184 (87,6\%) não recebiam. $O$ teste de anemia foi realizado com o hemoglobinômetro portátil Hemocue, e os pontos de corte adotados foram 11,0 e 11,5g/dL, segundo a faixa etária. Utilizouse regressão de Poisson hierarquizada com variância robusta para análise multivariada. Não houve diferença entre as prevalências de anemia entre os grupos beneficiários e não-beneficiários. Os fatores de risco para essa carência foram baixa escolaridade paterna, parto cesariano, consumo de água sem tratamento, baixa estatura e idade inferior a 24 meses. A prevalência de anemia no grupo de crianças menores de dois anos não-beneficiárias foi significantemente maior do que no grupo beneficiário de mesma idade, o que sugere a importância do benefício do PBF no combate à anemia em crianças.

Anemia; Programas Governamentais; Fatores de Risco; Renda

\section{Contributors}

R. M. M. Cotta was responsible for the study's conception, research supervision, and drafting and revising of the manuscript. F. C. C. Oliveira was responsible for the project's conception, data collection and analysis, and drafting of the manuscript. K. A. Magalhães, L. F. R. Sant'Ana, and S. E. Priore contributed to the study's conception and drafting of the manuscript. A. Q. Ribeiro contributed to the statistical analyses and drafting of the manuscript. S. C. C. Franceschini collaborated in the conception, data analysis, interpretation of the results, and revision of the manuscript.

\section{Acknowledgments}

The authors wish to thank the CNPq, grant no. 409795/2006-2, and the FAPEMIG, grants EDT-3332/06 and CDS - APQ - 4752 - 4.08/07, for funding the project, and the Paula Cândido Municipal Government (Prefeitura Municipal de Paula Cândido), especially nutritionist Karine Oliveira Gomes, for her support. 
1. Buss PM, Pelegrini Filho A. A saúde e seus determinantes sociais. Physis (Rio J.) 2007; 17:77-93.

2. Commission on Social Determinants of Health/ World Health Organization. Closing the gap in a generation: health equity through action on the social determinants of health. Final Report of the Commission on Social Determinants of Health. Geneva: World Health Organization; 2008.

3. Batista-Filho M, Souza AI, Bresani CC. Anemia como um problema de saúde pública: uma realidade atual. Ciênc Saúde Coletiva 2008; 13:1917-22.

4. McLean E, Cogswell M, Egli I, Wojdyla D, Benoist B. Worldwide prevalence of anemia in preschool aged children, pregnant women and non-pregnant women of reproductive age. In: Kraemer K, Zimmermann MB, editors. Nutritional anemia. Basel: Sight and Life Press; 2007. p. 1-12.

5. Benoist B, McLean E, Egli I, Cogswell M. Worldwide prevalence of anaemia, 1993-2005: WHO global database on anaemia. Geneva: World Health Organization; 2008.

6. Alderman H, Horton S. The economics of addressing nutritional anemia. In: Kraemer K, Zimmermann MB, editors. Nutritional anemia. Basel: Sight and Life Press; 2007. p. 19-35.

7. Duarte LM, Fujimori E, Minagawa AT, Schoeps FA, Montero RMJM. Aleitamento materno e níveis de hemoglobina em crianças menores de 2 anos em município do estado de São Paulo, Brasil. Rev Nutr 2007; 20:149-57.

8. Devincenzi MU, Ribeiro LC, Sigulem DM. Anemia ferropriva na primeira infância I. Compacta - Temas Nutrição Alimentar 2000; 1:5-17.

9. Instituto Brasileiro de Análises Sociais e Econômicas. Repercussões do Programa Bolsa Família na segurança alimentar e nutricional das famílias beneficiadas. Documento síntese. http://www.ibase. br/userimages/ibase_bf_sintese_site.pdf (accessed on 30/Oct/2008).

10. Brasil. Decreto $n^{\circ}$. 5.209 , de 17 de setembro de 2004. Regulamenta a Lei $n^{\circ}$. 10.836, de 9 de janeiro de 2004, que cria o Programa Bolsa Família e dá outras providências. Diário Oficial da União 2004; 20 set.

11. Gleason G, Scrimshaw N. An overview of the functional significance of iron deficiency. In: Kraemer K, Zimmermann MB, editors. Nutritional anemia. Basel: Sight and Life Press; 2007. p. 45-58.

12. Jelliffe DB. The assessment of the nutritional status of the community. Monogr Ser World Health Organ 1966; 53:3-271.

13. WHO Multicentre Growth Reference Study Group. WHO Child Growth Standards: length/height-forage, weight-for-age, weight-for-length, weight-forheight and body mass index-for-age: methods and development. http://www.who.int/childgrowth/ standards/em/index.html (accessed on 25/May/ 2006).

14. Silva DG, Franceschini SCC, Priore SE, Ribeiro SMR, Szarfarc SC, Souza SB, et al. Anemia ferropriva em crianças de 6 a 12 meses atendidas na rede pública de saúde do município de Viçosa, Minas Gerais. Rev Nutr 2002; 15:301-8.
15. Magalhães KA. Programa Bolsa Família: operacionalização, integração e desafios à emancipação de famílias em situação de vulnerabilidade social [Masters Thesis]. Viçosa: Universidade Federal de Viçosa; 2008.

16. Coutinho LMS, Scazufca M, Menezes PR. Métodos para estimar razão de prevalência em estudos de corte transversal. Rev Saúde Pública 2008; 42:992-8.

17. Victora CG, Huttly SR, Fuchs SC, Olinto MTA. The role of conceptual frameworks in epidemiological analysis: a hierarchical approach. Int J Epidemiol 1997; 26:224-7.

18. Silva LSM, Giugliani ERJ, Aerts DRGC. Prevalência e determinantes de anemia em crianças de Porto Alegre, RS, Brasil. Rev Saúde Pública 2001; 35:66-73.

19. Bueno MB, Selem SSC, Areas JAG, Fisberg RM. Prevalência e fatores associados à anemia entre crianças atendidas em creches públicas de São Paulo. Rev Bras Epidemiol 2006; 9:462-70.

20. Burlandy L. Transferência condicionada de renda e segurança alimentar e nutricional. Ciênc Saúde Coletiva 2007; 12:1441-51.

21. Almeida CAN, Ricco RG, Del Ciampo LA, Souza AM, Pinho AP, Dutra-de-Oliveira JE. Fatores associados à anemia por deficiência de ferro em crianças pré-escolares brasileiras. J Pediatr 2004; 80:229-34.

22. Assunção MCF, Santos IS, Barros AJD, Gigante DP, Victora CG. Anemia em menores de seis anos: estudo de base populacional em Pelotas, RS. Rev Saúde Pública 2007; 41:328-35.

23. Osório MM, Lira PIC, Ashworth A. Factors associated with $\mathrm{Hb}$ concentration in children aged 6-59 months in the state of Pernambuco, Brazil. Br J Nutr 2004, 91:307-14.

24. Muniz PT, Castro TG, Araujo TS, Nunes NB, SilvaNunes M, Hoffmann EHE, et al. Child health and nutrition in the Western Brazilian Amazon: population-based surveys in two counties in Acre State. Cad Saúde Pública 2007; 23:1283-93.

25. Ngnie-Teta I, Receveur O, Kuate-Defo B. Risk factors for moderate to severe anemia among children in Benin and Mali: insights from a multilevel analysis. Food Nutr Bull 2007; 28:76-89.

26. Osório MM. Fatores determinantes da anemia em crianças. J Pediatr (Rio J.) 2002; 78:269-78.

27. Silva DG, Priore SE, Franceschini SCC. Fatores de risco para anemia em lactentes atendidos nos serviços públicos de saúde: a importância das práticas alimentares e da suplementação com ferro. J Pediatr (Rio J.) 2007; 83:149-56.

28. Neuman NA, Tanaka OY, Szarfarc SC, Guimarães PRV, Victora CG. Prevalência e fatores de risco para anemia no Sul do Brasil. Rev Saúde Pública 2000; 34:56-63.

29. Netto MP, Priore SE, Sant'Ana HMP, Peluzio MCG, Sabarense CM, Silva DG, et al. Prevalência e fatores associados à anemia e deficiência de ferro em crianças de 18 a 24 meses. Arch Latinoam Nutr 2006; 56:229-36. 
30. Matta IEA, Veiga GV, Baiao MR, Santos MMAS, Luiz RR. Anemia em crianças menores de cinco anos que frequentam creches públicas do município do Rio de Janeiro, Brasil. Rev Bras Saúde Matern Infant 2005; 5:349-57.

31. Guyatt HL, Brooker S, Kihamia CM, Hall A, Bundy DAP. Evaluation of efficacy of school-based anthelmintic treatments against anaemia in children in the United Republic of Tanzania. Bull World Health Organ 2001; 79:695-703.

32. Tsuyuoka R, Bailey JW, Guimarães AMAN, Gurgel RQ, Cuevas LE. Anemia and intestinal parasitic infections in primary school students in Aracaju, Sergipe, Brazil. Cad Saúde Pública 1999; 15:413-21.

33. Ferreira HS, Assunção ML, Vasconcelos VS, Melo FP, Oliveira CG, Santos TO. Saúde de populações marginalizadas: desnutrição, anemia e enteroparasitoses em crianças de uma favela do "Movimento dos Sem Teto”, Maceió, Alagoas. Rev Bras Saúde Matern Infant 2002; 2:177-85.
34. Olivares M, Walter T. Causas y consecuencias de la deficiencia de hierro. Rev Nutr 2004; 17:5-14.

35. Rocha DS, Lamounier JA, Capanema FD, Franceschini SCC, Norton RC, Costa ABP, et al. Estado nutricional e prevalência de anemia em crianças que frequentam creches em Belo Horizonte, Minas Gerais. Rev Paul Pediatr 2008; 26:6-13.

36. Warrier RP, Dole MG, Warrier J, Suskind RM. The anemia of malnutrition. In: Suskind RM, LewinterSuskind L, editors. The malnourished child. New York: Nestlé/Raven Press; 1990. p. 71-2. (Nestlé Nutrition Workshop Series, 19).

Submitted on 06/May/2010

Final version resubmitted on 17/Sep/2010 Approved 03/Jan/2011 